\title{
The Development of the Method and Determination of the Relative Abrasiveness of Bulk Substances
}

\author{
Gulmira Akimbek ${ }^{1, *}$, Birlesbek Aliyarov ${ }^{1}$, and Shyryn Akimbekova ${ }^{2}$ \\ ${ }^{1}$ Almaty University of Energy and Communications named after G.Daukeev, 050013 Almaty, \\ Kazakhstan \\ ${ }^{1}$ Almaty University of Energy and Communications named after G.Daukeev, 050013Almaty, \\ Kazakhstan \\ ${ }^{2}$ Kazakh National Agrarian University, 050000 Almaty, Kazakhstan
}

\begin{abstract}
This article touches upon the preliminary results of determining the coefficient of relative abrasiveness of various bulk materials. An experimental setup for determining the abrasiveness of various bulk materials is described, which makes it possible to set the abrasiveness of a material with different physical properties and fractions of the frayed material.It is noted that during experiments it is necessary to ensure the stability of fractions. It is scheduled to determine the critical speed of movement of bulk solids, which eliminates the change in fraction size through grinding when the test material is abraded by samples. It is emphasized that the abrasiveness of the test material is determined on the material recognized as a reference.
\end{abstract}

\section{The relevance of the research}

Coal in the world in its reserves is ten times higher than other types of organic fuel (oil, gas) and therefore it can be considered the fuel of the future. In addition, coal is undoubtedly a technological raw material [1]. In particular, Kazakhstan has about $3.3 \%$ of the world's industrial coal reserves (table 1).

Table 1. Coal Reserves and production volumes in the regions of Kazakhstan (million tons)

\begin{tabular}{|l|l|l|l|l|l|l|}
\hline $\begin{array}{l}\text { Economic } \\
\text { area }\end{array}$ & $\begin{array}{l}\text { Coal } \\
\text { category }\end{array}$ & $\begin{array}{l}\text { Geological } \\
\text { reserves }\end{array}$ & $\begin{array}{l}\text { Balance } \\
\text { stock }\end{array}$ & $\begin{array}{l}\text { Industrial } \\
\text { stock }\end{array}$ & $\begin{array}{l}\text { Productio } \\
\text { n in 1995 }\end{array}$ & $\begin{array}{l}\text { Project } \\
\text { productio } \\
\text { n }\end{array}$ \\
\hline $\begin{array}{l}\text { (1)Eastern } \\
\text { Kazakhstan }\end{array}$ & & 4500 & 3040 & & & \\
\hline $\begin{array}{l}\text { Kendyrlyk } \\
\text { municipal } \\
\text { area }\end{array}$ & stony & 586 & 191 & 77 & & $\begin{array}{c}\text { Total } \\
1,0-2,0\end{array}$ \\
\cline { 2 - 7 } & brown & 1033 & 400 & 169 & & up to 1,0 \\
\hline
\end{tabular}

* Corresponding author: akimbekg@mail.ru 


\begin{tabular}{|c|c|c|c|c|c|c|}
\hline $\begin{array}{l}\text { municipal } \\
\text { area }\end{array}$ & & & & & & \\
\hline $\begin{array}{l}\text { Jubileinyi } \\
\text { municipal } \\
\text { area }\end{array}$ & brown & 1536 & & & 1,4 & 30,0 \\
\hline $\begin{array}{l}\text { (2)Western } \\
\text { Kazakhstan }\end{array}$ & & 2900 & 1790 & & & \\
\hline $\begin{array}{l}\text { Ural-Caspian } \\
\text { basin. }\end{array}$ & brown & 378 & 108 & 96 & & 5,0 \\
\hline $\begin{array}{l}\text { Mamyt } \\
\text { municipal } \\
\text { area }\end{array}$ & brown & 1426 & 1320 & 598 & & 3,0 \\
\hline $\begin{array}{l}\text { (3)Northern } \\
\text { Kazakhstan }\end{array}$ & & 81800 & 18520 & & & \\
\hline $\begin{array}{l}\text { Ekibastuz } \\
\text { basin }\end{array}$ & stony & 12500 & 9700 & 7700 & 62,2 & up to 105 \\
\hline $\begin{array}{l}\text { Mycubensk } \\
\text { municipal } \\
\text { area } \\
\end{array}$ & brown & 5700 & 1805 & 1767 & 0,3 & $15,0-25,0$ \\
\hline Torgai basin & brown & 61910 & 6564 & 5933 & & 2,0 \\
\hline $\begin{array}{l}\text { (4)Central } \\
\text { Kazakhstan }\end{array}$ & & 54500 & 14800 & & & \\
\hline $\begin{array}{l}\text { Karaganda } \\
\text { basin. }\end{array}$ & stony & 51300 & 15800 & 7500 & 14,4 & up to 25,0 \\
\hline $\begin{array}{l}\text { Kutcherinsk } \\
\text { municipal } \\
\text { area }\end{array}$ & stony & 600 & 150 & 150 & & $1,8-3,0$ \\
\hline $\begin{array}{l}\text { Borlinsk } \\
\text { municipal } \\
\text { area }\end{array}$ & stony & 490 & 314 & & 3,1 & 10,0 \\
\hline $\begin{array}{l}\text { Shubarkol } \\
\text { municipal } \\
\text { area }\end{array}$ & stony & 2100 & 1700 & & 1,8 & $22,0-28,0$ \\
\hline $\begin{array}{l}\text { (5)Southern } \\
\text { Kazakhstan }\end{array}$ & & 33000 & 480 & & & \\
\hline $\begin{array}{l}\text { Oikaragai } \\
\text { municipal } \\
\text { area }\end{array}$ & brown & 74 & 53,4 & 40,2 & & $0,3-0,5$ \\
\hline $\begin{array}{l}\text { Nizhneilisk } \\
\text { municipal } \\
\text { area } \\
\end{array}$ & brown & 9878 & & & & 80,0 \\
\hline $\begin{array}{l}\text { Alakol } \\
\text { municipal } \\
\text { area } \\
\end{array}$ & stony & 130 & 50 & & & 0,3 \\
\hline $\begin{array}{l}\text { Lenger } \\
\text { municipal } \\
\text { area }\end{array}$ & brown & 2109 & 751 & 355 & & \\
\hline $\begin{array}{l}\text { (6)Total for } \\
\text { Kazakhstan }\end{array}$ & & 176700 & 38630 & 34100 & 83,2 & \\
\hline
\end{tabular}

This table shows that coal (in contrast to oil and gas) is in almost all regions of Kazakhstan. In relation to the reserves to the volume of coal production achieved by 2015, Kazakhstan can be considered a country with unlimited reserves. 
Approximately $80 \%$ of Kazakhstan's thermal power plants use coal as fuel. In the process of burning coal at thermal power stations, different properties of coal interact with different elements of the equipment in different ways [1].

Power engineers, when assessing the quality of fuel supplied to thermal power stations and pay attention to and, accordingly, determine the following characteristics:

- grinding capacity-determines the productivity and duration of operation of crushing and/or grinding equipment,

- bulk properties-affect the continuity of coal supply from various bunkers,

-inclination to oxidation - it defines two processes :possible fire in stacks and reduced calorific value during long-term storage,

- the fusibility of the mineral part-affects the choice of the scheme for removing slag from the furnace and the choice of the temperature at the outlet of the furnace and the height of the boiler;

- the abrasiveness of the fraction of crushed and / or crushed coal and the resulting fly ash - it determines the choice of the speed of their movement in the boiler elements [1].

One of the physical characteristics of coal, which is required for use in the power industry is its abrasiveness.

Coal, when it moves from the cars to the furnace, wears out many elements of the fuel economy of the station. The most frequently worn out grinding elements of crushers and mills, hopper walls, feeders, dumpers on conveyors, and others. However, until recently, there are no studies necessary to determine their abrasive wear, including the abrasiveness of coal grains [2].

Well-known studies are devoted to determining the intensity of abrasive wear coal grains crushed in mills to sizes at the level of 100 microns or less, or formed when they are burned by fuel ash fractions ( the same or smaller sizes), usually moving in the flow of air or flue gases. It should be noted that in these studies, the abrasiveness of the material was determined indirectly - through the intensity of erosion wear, without directly determining the abrasiveness. There was virtually no data on wear by fractions with dimensions corresponding to crushing interacting with the surface of the elements, in the absence of carrier air or other gaseous substance [2].

\section{Description of the installation and preliminary results}

To study and determine the abrasive properties of (crushed) coal, an installation very similar to an unventilated mill was developed by Almaty University of Energy and Communications named after Gumarbek Daukeev, the General view is shown in figure 1.
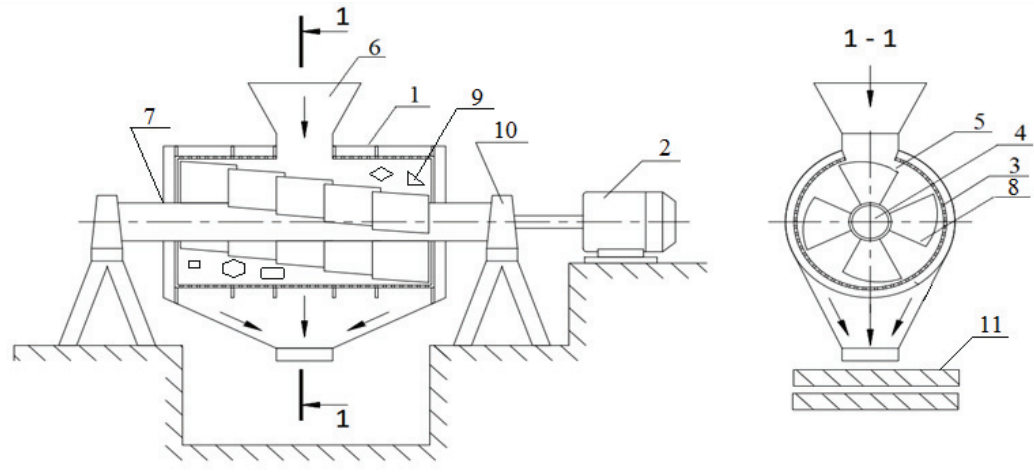

Fig.1. a) Experimental setup - Description: 1) bearing, 2) electric motor with adjustable speed, 3) outer cylinder, 4) rotating cylinder for mounting samples, 5) volume for filling the test material, 6) hatch for loading the test material, 7) connectors for separating the upper part of the outer cylinder 
from the lower one, 8) sample mounting systems, 9) test samples, 10) installation supports 11) device for monitoring the frequency of rotation of the rod, a) a set of sieves (screens) to control the size of the test material.

The process of determining the abrasive capacity of the material is carried out as follows. Initially, the test material is crushed to the specified fractions. Then the material is passed through a system of screens or sieves to produce fractions with the specified dimensions. The resulting material (after determining the type of fraction faces) is loaded into the hopper and fed into the space between the outer cylinder and the sample rod, and the filling level of this space is monitored and fixed. The effect of the filling level of this space on the wear rate is one of the subjects of research.

The closest, in technical essence, to the created installation can be considered a device for determining the grinding capacity of coals, called relative laboratory, since it is carried out on a laboratory installation and the propensity to grind is defined relative to the reference material [3]. This setting allows you to determine the degree of grinding of various coals, when rotating at a given speed for a certain period (in an unventilated mill (ball or other). The propensity to grind is determined by the ratio of the proportion of residue on the screen with a given cell size of the reference and test material.

In the created installation for determining the abrasiveness of bulk solids, on the contrary, the possibility of changing the particle size during experiments is excluded. In particular, after a certain period of time, the wear material is completely unloaded and the preservation of the original fractions and faces of the material under study is checked. Determining this kind of critical speed of mutual movement of the samples and the wear material is also one of the parameters of the study.

The created installation allows you to conduct experiments with different materials, with different sizes, shapes and faces of wear fractions. The abrasiveness of the material is also determined indirectly by the wear of the samples.

The mounting system allows the installation of samples of various shapes at different angles. One of the most difficult tasks in these experiments is the selection of the reference material.

Naturally, the use of a relatively easy-to-wear material is desirable for samples. Determination of the most acceptable material (by usability and applicability of the results to generalization for other materials) is also included in the subject of the study.

Figure 1 shows data from preliminary studies of the effect of the relative velocity of the sample and material (quartz sand) on the wear rate, which shows predictable results of increasing wear as the speed increases. Processing of these data with the exception of the influence of speed and represent the desired value of the abrasiveness of the bulk material.

The analysis shows that the abrasiveness of a particular bulk material depends significantly on many parameters: size, shape, and the resulting faces. In this regard, as a result of research, a kind of nomogram of the abrasiveness of bulk solids will be compiled, which will allow us to reliably predict the intensity of future abrasive wear. It is possible to calculate the predicted wear by bulk solids using a formula similar to that used for predicting abrasive wear by fly ash:

$$
\mathrm{K}_{\mathrm{ao}}=\mathrm{f} \cdot \mathrm{p} \frac{h \cdot g}{E \cdot C \cdot w^{-3} \cdot \tau}
$$

Here, (h) is the rate of change of sample weight during the experiment (grams); (E) coefficient of fraction strikes; (C) the concentration of bulk substances (it may be replaced by the level of filling of the installation with the test sample), $\mathrm{kg} / \mathrm{m}^{3}$; (w) relative velocity of fractions and sample, $\mathrm{m} / \mathrm{c} ;(\tau)$ the time, hour; (f) coefficient that takes into account the shape of the sample; (p) coefficient that takes into account the shape of the fraction faces of the material under study. 
The determination of the components of this equation when changing the main parameters of the wear material particles, the shape of their interaction are the subject of future research.

\section{Conclusion}

An installation has been created that allows determining the abrasiveness of fractions of different materials, with different sizes and shapes at different interaction speeds. Preliminary results of the interaction rate influence on the wear rate of bulk solids are presented.

\section{References}

1. B. Aliyarov. Kazakhstan coal burning at thermal power plants and large boilers: experience and prospects. Almaty, (2011)

2. A. Beron, V. Soloviev. Device for studying the abrasiveness of coal. - "Bulletin of inventions № 266687» (1970)

3. Method for determining the grinding capacity of various coals. Thermal measurements (1993)

4. The brown coals, hard coals and anthracite. Method for determining the ash abrasiveness coefficient (1976)

5. S. F. Scieszka Simultaneous abrasion and edge fracture resistance estimation of hard materials by the tribotesting method. ZEM, (2 (166) vol. 46, 2011) 